\title{
PVM/MA-shelled selol nanocapsules promote cell cycle arrest in A549 lung adenocarcinoma cells
}

\author{
Ludmilla Regina de Souza', Luis Alexandre Muehlmannn², Mayara Simonelly Costa dos Santos ${ }^{1}$, Rayane Ganassin², \\ Rosana Simón-Vázquez ${ }^{3}$, Graziella Anselmo Joanitti ${ }^{2}$, Ewa Mosiniewicz-Szablewska ${ }^{4}$, Piotr Suchocki ${ }^{5,6}$, \\ Paulo César Morais ${ }^{7,8}$, África González-Fernández ${ }^{3}$, Ricardo Bentes Azevedo ${ }^{2}$ and Sônia Nair Báo ${ }^{2^{*}}$
}

\begin{abstract}
Background: Selol is an oily mixture of selenitetriacylglycerides that was obtained as a semi-synthetic compound containing selenite. Selol is effective against cancerous cells and less toxic to normal cells compared with inorganic forms of selenite. However, Selol's hydrophobicity hinders its administration in vivo. Therefore, the present study aimed to produce a formulation of Selol nanocapsules (SPN) and to test its effectiveness against pulmonary adenocarcinoma cells (A549).

Results: Nanocapsules were produced through an interfacial nanoprecipitation method. The polymer shell was composed of poly (methyl vinyl ether-co-maleic anhydride) (PVM/MA) copolymer. The obtained nanocapsules were monodisperse and stable. Both free Selol (S) and SPN reduced the viability of A549 cells, whereas S induced a greater reduction in non-tumor cell viability than SPN. The suppressor effect of SPN was primarily associated to the G2/M arrest of the cell cycle, as was corroborated by the down-regulations of the CCNB1 and CDC25C genes. Apoptosis and necrosis were induced by Selol in a discrete percentage of A549 cells. SPN also increased the production of reactive oxygen species, leading to oxidative cellular damage and to the overexpression of the GPX1, CYP1A1, BAX and BCL2 genes.
\end{abstract}

Conclusions: This study presents a stable formulation of PVM/MA-shelled Selol nanocapsules and provides the first demonstration that Selol promotes G2/M arrest in cancerous cells.

\section{Background}

Low therapeutic efficacy and drug resistance are the most common problems related to the currently available chemotherapeutic agents used in tumoral clinical application. In the search for new chemotherapeutic drugs, several selenium (Se) compounds shown anticancer and anticarcinogenic activities $[1,2]$. In particular, those containing Se at its $4+$ oxidation state, namely selenite, present the highest antioxidant and anticancer activities [2]. However, Se(IV)containing compounds generally present high systemic toxicity, limiting their clinical application. In this context, a selenite-containing compound named Selol, which was first obtained at Warsaw Medical University, Poland [3], has shown antitumor activity and low systemic toxicity $[4,5]$. Selol is a mixture of different selenitetriacylglycerides

\footnotetext{
*Correspondence: snbao@unb.br

${ }^{2}$ Institute of Biological Sciences, University of Brasília, Brasília, DF 70910-900, Brazil

Full list of author information is available at the end of the article
}

and appears to act primarily through the induction of oxidative stress in cancer cells [5]. Interestingly, Selol was shown to sensitize leukemia cells to the cytotoxicity of vincristine and doxorubicin, insomuch that it was suggested that Selol could be used in combination with other drugs in chemotherapeutic protocols [4].

The potential synergism of Selol with classical anticancer drugs can be exploited to treat tumors, such as nonsmall cell lung cancer (NSCLC) [4]. NSCLC, whose most frequently observed histological subtype is adenocarcinoma, is particularly aggressive and the leading cause of cancer death worldwide [6,7]. It is estimated that more than $75 \%$ of patients with NSCLC present locally advanced or metastatic disease, severely limiting the success of treatments $[8,9]$. Platinum-based treatment, which is the most recommended first-line therapy, reaches response rates of only $20-40 \%$ and mean survivals between 7 and 12 months $[8,10,11]$. Multidrug protocols and a treatment break with non-platinum-based drugs after a fixed 
course of initial chemotherapy have been shown to prolong the survival of NSCLC patients [12,13]. Thus, Selol may be a potential candidate for combined anti-NSCLC strategies [14].

Despite the therapeutic potential presented by Selol, its hydrophobicity is a major obstacle to its biological application. For instance, high hydrophobicity often hinders intravenous (iv) administration and may thus confer an undesirable pharmacokinetic profile [15]. This problem can be circumvented through the nanoencapsulation of Selol in an aqueous vehicle to form a nanocapsulebased drug delivery system. The nanoencapsulation of Selol with a polymer presenting highly reactive chemical groups allowing surface modification could bring up new possibilities for delivering this anticancer agent. In this context, the copolymer poly(methyl vinyl ether-comaleic anhydride) (PVM/MA) has been reported to be a biocompatible and biodegradable material useful for preparing drug delivery systems [16]. Additionally, the copolymer PVM/MA presents a surfactant effect and anhydride groups, which readily react with a series of molecules. On that ground, we report the development and the first in vitro efficacy tests of a PVM/MA-shelled Selol nanocapsule formulation intended for the treatment of lung adenocarcinomas.

\section{Results and discussion}

\section{Formulation screening}

The interfacial precipitation method of preformed polymer through solvent displacement yields nanosized Selol capsules only within a certain range of solute and solvent concentrations. Thus, to identify the best formulation parameters, different concentrations of each component were tested.

First, different Selol-to-PVM/MA ratios were tested $(0.1,0.2,0.5,0.7,1.0,1.5,2.0$, and $4.0, \mathrm{w}: \mathrm{w})$, and the concentrations of acetone, ethanol and water were fixed to 20, 40 and 40\% (v:v), respectively. As shown in Figure 1 (a), the increase in this ratio led to a directly proportional increase in the hydrodynamic diameter (HD) values of the nanocapsules. Using Selol-to-PVM/MA ratios from 0.1 to 1.0 , monodisperse nanocapsule populations were obtained, and the polydispersity index (PDI) values remained below 0.1. Formulations prepared with Selol-to-PVM/MA ratios higher than 1.0 showed visible decantation minutes after preparation and were not used for dynamic light scattering analysis. Therefore, this parameter was set to 1.0 for the next steps because this was the highest value that allowed stable nanocapsules to be obtained.

Next, different concentrations of Selol plus PVM/MA were tested. The concentrations of acetone, ethanol and water were set to 20,40 and $40 \%(\mathrm{v}: \mathrm{v})$, respectively. As expected, smaller nanocapsules were obtained at the lowest concentrations of Selol plus PVM/MA (Figure 1 (b)). The PDI was not significantly affected by this variable, remaining close to 0.1 . The concentration of Selol plus PVM/MA was set to $0.8 \%$ (w:v) in further experiments because it provided good colloidal characteristics in addition to a good yield of nanocapsules.

Then, different concentrations of acetone and ethanol were tested in the process of encapsulation with $0.8 \%$ Selol plus PVM/MA and a ratio of 1.0 Selol-to-PVM/ MA. Different volumes of acetone were used for dissolving a fixed amount of Selol and PVM/MA, and the final volume reached $100 \%$ with ethanol:water $(1: 1, \mathrm{v}: \mathrm{v})$. As shown in Figure 1(c), a major change in the nanocapsule HD was observed with $40 \%$ acetone, but the PDI remained below 0.1 . When the concentration of acetone was set to $20 \%$ and varying volumes of ethanol were added, it was observed that the HD of the nanocapsules decreased with higher concentrations of ethanol (Figure 1 (d)). The highest HD and PDI values were obtained with $20 \%$ ethanol.

Given the results described above, the protocol of Selol nanoencapsulation was established as follows: 1) $100 \mathrm{mg}$ of PVM/MA and $100 \mathrm{mg}$ of Selol were dissolved in $5 \mathrm{~mL}$ of acetone; 2) $10 \mathrm{~mL}$ of ethanol and $10 \mathrm{~mL}$ of water were added; and 3) the purification steps were then performed.

The method of nanoprecipitation by solvent displacement yielded monodisperse nanocapsules at almost all of the conditions tested and also allowed modulation of the nanocapsule diameter. Noteworthy, by varying the concentrations of acetone and ethanol, nanocapsules of different HDs were obtained, likely due to differences in solvent diffusion, as previously suggested [17]. Even for a concentration of nanocapsule components (Selol plus PVM/MA) near the upper critical limit of $2 \%$, as noted by Aubry et al. (2009) [18] for this method, stable and monodisperse nanocapsules were obtained. As expected, at higher concentrations of Selol, larger capsules were obtained, which can be attributed to the nucleation-andgrowth phenomenon $[19,20]$.

\section{Characterization of Selol nanocapsules}

The Selol nanocapsules (SPN) formulation presented a single population of nanocapsules with an HD of 344.4 \pm $4.8 \mathrm{~nm}$, a PDI of $0.061 \pm 0.005$ and a zeta potential ( $\zeta$ po tential) of $-29.3 \mathrm{mV} \pm 1.5$. The transmission electron microscope (TEM) image revealed a population of nanocapsules with an average diameter of $207.9 \pm 80.9 \mathrm{~nm}$ (Figure 1(e)). These nanometric structures presented a spherical shape and slightly rough surface, as observed with a scanning electron microscope (SEM) (Figure 1(f)). A spherical equilibrium shape is expected with this method due to the three-dimensional primordial droplet nuclei growth conferred by the interfacial tension between the droplets and the dispersant $[20,21]$. Furthermore, according to the 

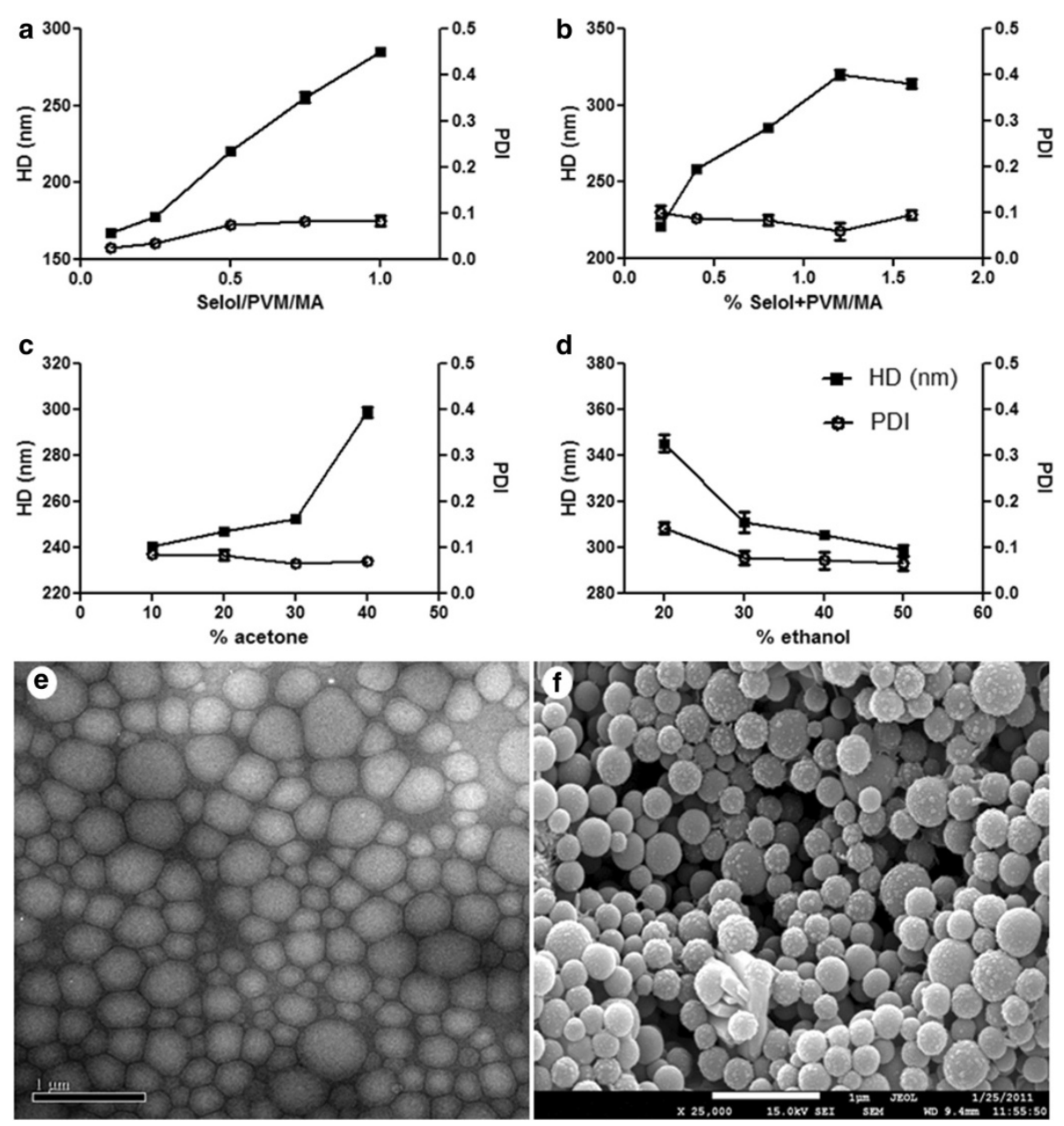

Figure 1 Characterization of Selol nancapsules. Values of the hydrodynamic diameters (HD) (in squares) and polydispersity indexes (PDI) (in diamond) of PVM/MA-shelled Selol nanocapsules as a function of the Selol-to-PVM/MA ratio (a), concentration of Selol plus PVM/MA (b), acetone (c), and ethanol (d). Morphology of Selol-PVM/MA nanocapsules (SPN) observed by TEM (e) and SEM (f). Magnification: $25.000 \times$.

TEM images, the Selol nanocapsules appear to be deformable. Both the deformability and the spherical shape of the nanocapsules are interesting for their administration through parenteral routes [22].

The dosage of the purified Selol nanocapsules showed that the concentration of Selol measured in the nanocapsule was approximately $100 \%$ of the initial amount of Selol used in the process. Supported by the low PDI of the Selol composition, this result confirms that Selol was efficiently encapsulated into the PVM/MA shell. However, it was necessary to evaluate the copolymer's capacity for interfacial stabilization after prolonged periods of storage and thermal stress conditions. As observed in Table 1, the SPN was stable at room temperature (RT) for at least 60 days. Under these conditions, there was no statistically significant change in the HD over the evaluated period of time. When stored at $4^{\circ} \mathrm{C}$, the SPN average HD increased by approximately $40 \mathrm{~nm}$ on the first day and then remained stable. At both $\mathrm{RT}$ and $4^{\circ} \mathrm{C}$, the PDI remained well below 0.1, showing that the nanocapsules remained monodisperse. At $-20^{\circ} \mathrm{C}$, significant variations were observed in both the HD and PDI $(>0.3)$, indicating that this condition is not adequate for storage. After freezing/thawing cycles, no significant changes in both the HD and PDI ( $>0.05)$ were found up to the eighth cycle. Indeed, PVM/MA presented good capacity for interfacial stabilization in SPN because this system did not present any important changes in its characteristics, neither after 60 days of storage (at RT or $4^{\circ} \mathrm{C}$ ) nor after being subjected to the thermal stress of eight cycles of freezing/thawing. The $\zeta$ potential of the nanocapsules was generally between -25 and $-30 \mathrm{mV}$ at all of the conditions tested, which is due to the presence of carboxylate groups on their outer surface. A hypothetical scheme of the PVM/MA-shelled Selol nanocapsules is shown in Figure 2. Over the course of encapsulation, the PVM/ 
Table 1 Thermodynamic stability and dispersibility studies of Selol-PVM/MA nanocapsules

\begin{tabular}{|c|c|c|c|}
\hline Formulation & Hydrodynamic diameter \pm S.D. $(\mathrm{nm})$ & Polydispersity index & Zeta potential $(\mathrm{mV})$ \\
\hline \multicolumn{4}{|c|}{ Room temperature } \\
\hline Day 0 & $344.4 \pm 4.8^{\mathrm{a}}$ & 0.061 & -29.3 \\
\hline Day 15 & $349.7 \pm 8.2^{\mathrm{a}}$ & 0.049 & -29.7 \\
\hline Day 30 & $338.9 \pm 6.4^{a}$ & 0.046 & -29.2 \\
\hline Day 45 & $344.3 \pm 2.0^{a}$ & 0.034 & -26.5 \\
\hline Day 60 & $336.6 \pm 4.6^{\mathrm{a}}$ & 0.043 & -29.4 \\
\hline \multicolumn{4}{|l|}{$4^{\circ} \mathrm{C}$} \\
\hline Day 0 & $344.4 \pm 4.8^{\mathrm{a}}$ & 0.061 & -29.3 \\
\hline Day 1 & $390.2 \pm 1.0^{b}$ & 0.054 & -29.3 \\
\hline Day 15 & $391.3 \pm 7.5^{b}$ & 0.044 & -25.1 \\
\hline Day 30 & $373.9 \pm 15.0^{\mathrm{b}}$ & 0.046 & -27.8 \\
\hline Day 45 & $381.6 \pm 8.9^{\mathrm{b}}$ & 0.031 & -30.1 \\
\hline Day 60 & $380.6 \pm 7.1^{\mathrm{b}}$ & 0.039 & -27.3 \\
\hline \multicolumn{4}{|l|}{$-20^{\circ} \mathrm{C}$} \\
\hline Day 0 & $344.4 \pm 4.8^{\mathrm{a}}$ & 0.061 & -29.3 \\
\hline Day 1 & $414.2 \pm 7.7^{c}$ & 0.074 & -29.2 \\
\hline Day 15 & $408.2 \pm 10.7^{c}$ & 0.113 & -27.0 \\
\hline Day 30 & $471.0 \pm 1.3^{\mathrm{d}}$ & 0.195 & -27.4 \\
\hline Day 45 & $615.2 \pm 13.3^{\mathrm{e}}$ & 0.278 & -29.8 \\
\hline Day 60 & $566.3 \pm 14.8^{f}$ & 0.196 & -26.5 \\
\hline \multicolumn{4}{|c|}{ Freezing $\left(-20^{\circ} \mathrm{C}\right)$ and thawing cycle } \\
\hline No cycle & $344.4 \pm 4.8$ & 0.061 & -29.3 \\
\hline । & $414.2 \pm 7.74$ & 0.074 & -29.2 \\
\hline$\|$ & $414.1 \pm 10.0$ & 0.066 & -28.9 \\
\hline III & $406.7 \pm 4.5$ & 0.035 & -28.9 \\
\hline IV & $410.2 \pm 4.7$ & 0.045 & -28.1 \\
\hline V & $416.5 \pm 4.3$ & 0.064 & -22.9 \\
\hline $\mathrm{VI}$ & $405.5 \pm 6.0$ & 0.046 & -28.5 \\
\hline VII & $425.8 \pm 0.9$ & 0.079 & -28.8 \\
\hline VIII & $467.3 \pm 9.9$ & 0.143 & -27.0 \\
\hline IX & $486.5 \pm 17.1^{*}$ & 0.106 & -28.8 \\
\hline$x$ & $495.1 \pm 1.0^{*}$ & 0.177 & -30.8 \\
\hline$X I$ & $509.3 \pm 6.6^{*}$ & 0.221 & -28.9 \\
\hline XII & $566.2 \pm 3.5^{*}$ & 0.364 & -28.7 \\
\hline XIII & $865.1 \pm 50.4^{*}$ & 0.581 & -27.7 \\
\hline XIV & $989.1 \pm 26.6^{*}$ & 0.433 & -26.9 \\
\hline$X V$ & $1027.5 \pm 60.7^{*}$ & 0.393 & -28.8 \\
\hline
\end{tabular}

All values were expressed as the means \pm standard error of the mean. Different letters indicate significant differences between SPN treatment for one day at $\mathrm{RT}$ compared with a given time and/or storage condition $(p<0.05)$. ${ }^{*}$ Significantly different compared with the first cycle of freezing $\left(-20^{\circ} \mathrm{C}\right)$ and thawing $(p<0.05)$.

MA copolymer, which is poorly soluble in water, becomes amphipathic due to the hydrolysis of some of its anhydride groups exposed to water. The formed polymer shell presents a hydrophilic water-exposed surface, facilitating the stabilization of nanocapsules.
Selol nanocapsules affect cell viability in a concentrationand time-dependent manner

The MTT assay showed that nanoparticles of PVM/MA without Selol $(\mathrm{Bl})$ did not significantly affect the viability of the studied cells (Figure 3). Significant reductions in 


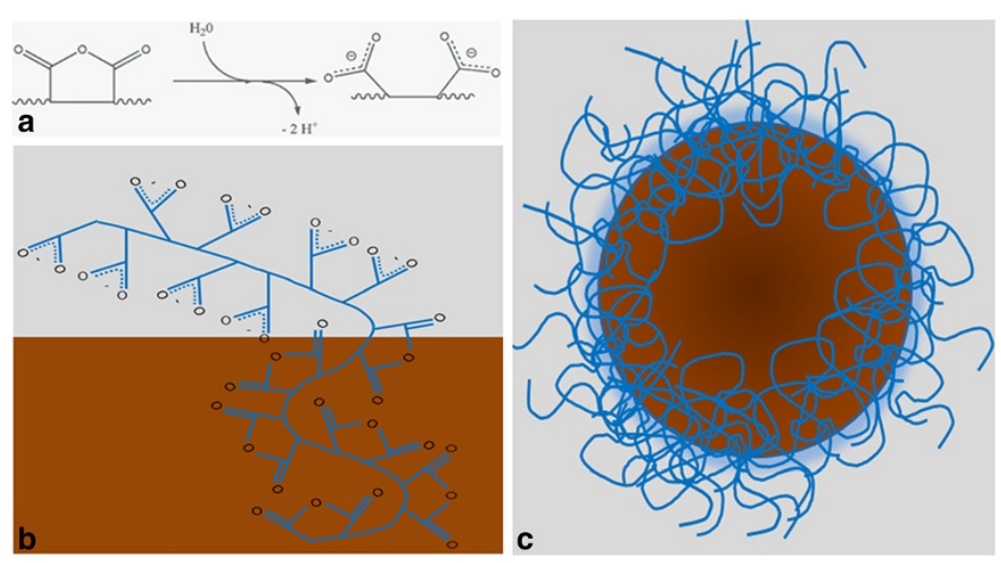

Figure 2 Schematic representation of PVM/MA-shelled Selol nanocapsules. Hydrolysis of an anhydride group yields two carboxylate groups at neutral pH in a PVM/MA strand (a). Partial hydrolysis of the PVM/MA polymer strand exposed to water but not in PVM/MA closer to the oily core (b). The carboxylate-containing parts of PVM/MA are hydrophilic and comprise the nanocapsule shell surface, whereas the anhydride-containing parts are more hydrophobic, closely covering the Selol core (c).
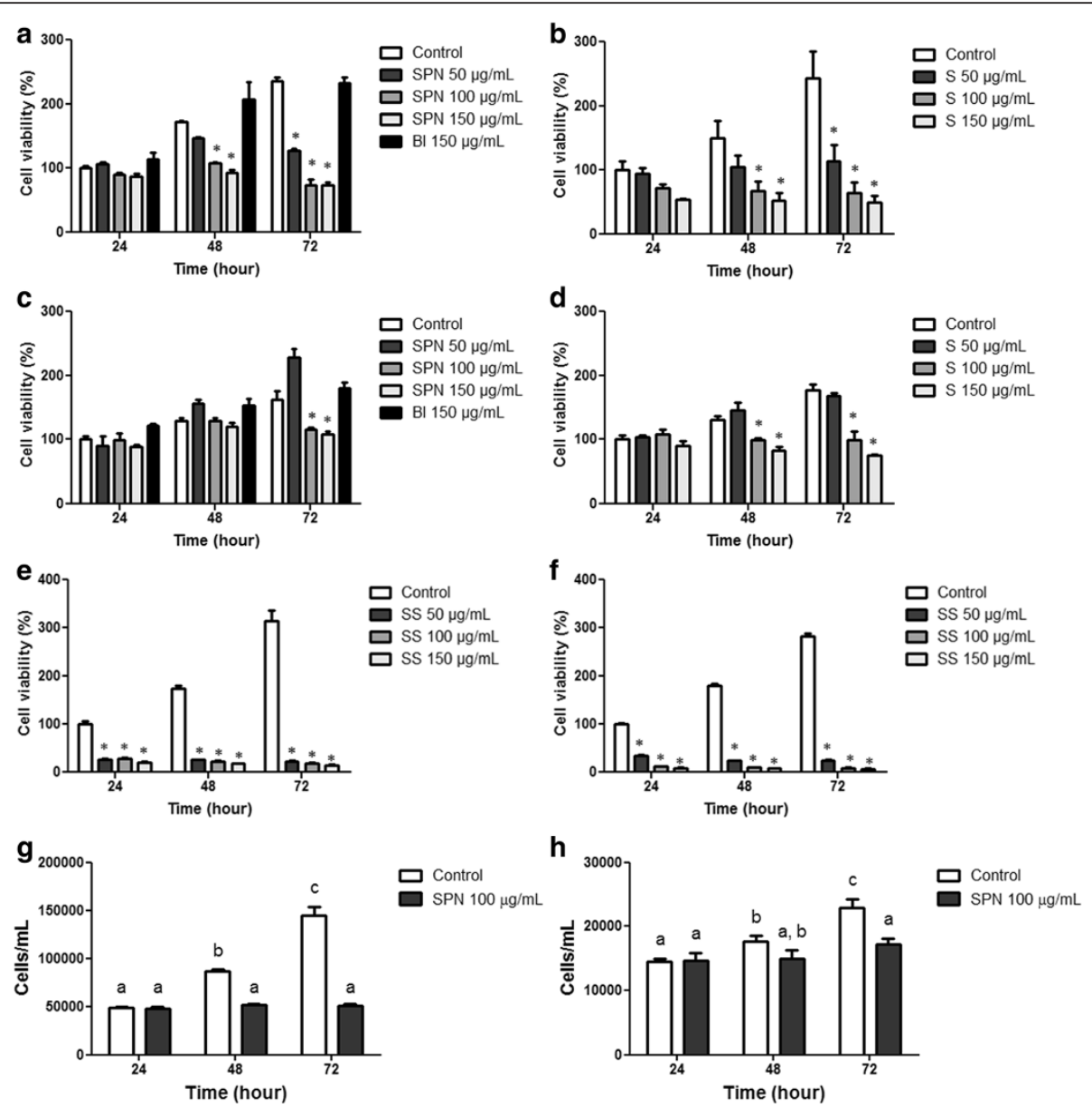

Figure 3 Viability of A549 (a, b, e) and human connective tissue (c, d, f) cells after exposure to Selol-PVM/MA nanocapsules (SPN) $(a, c)$, free Selol (S) (b, d), blank polymeric nanoparticles without Selol (BI) (a, c) or sodium selenite (SS) (e, f) at 50, $100 \mathrm{and} 150 \mu \mathrm{g} / \mathrm{mL}$

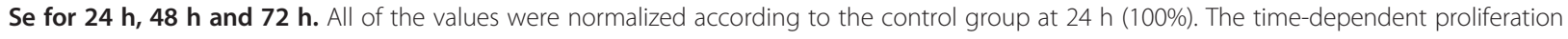
of control cells was significantly different. *Statistically significant compared with the control group at the corresponding treatment period ( $p<0.05$ ). Influence of SPN at a concentration of $100 \mu \mathrm{g} \mathrm{Se} / \mathrm{mL}$ on the proliferation of A549 $\mathbf{( g )}$ and human connective tissue (h) cells evaluated after different treatment times. Pairs of means in a same graph identified with different letters are significantly different $(p<0.05)$. 
the viability of human lung adenocarcinoma (A549) cells were observed after exposure to SPN or free Selol (S) at concentrations of $50 \mu \mathrm{g} / \mathrm{mL}$ for $72 \mathrm{~h}$ and 100 and $150 \mu \mathrm{g} / \mathrm{mL}$ for 48 and $72 \mathrm{~h}(\mathrm{p}<0.05)$. In contrast, tissue connective normal cells were shown to be less sensitive to Selol compared with tumor cells. Free Selol treatment reduced the viability of normal cells after $48 \mathrm{~h}$, whereas SPN reduced their viability only after $72 \mathrm{~h}$ of incubation. Sodium selenite (SS) was highly toxic for both cell types at all concentrations and times tested. The high toxicity of SS toward normal cells shows that selenite is an effective anticancer agent but is not safe for clinical use in its inorganic form. Therefore, some researchers have aimed to find organic selenium compounds with higher therapeutic indexes [23,24]. Selol, an organic selenite compound, significantly reduced the viability of lung adenocarcinoma A549 cells but was far less toxic on normal cells than sodium selenite. This finding reinforces the previously shown evidence that Se $(4+)$ organified as Selol has a significantly lower potential to exert deleterious effects on non-target tissues than its inorganic form $[4,25,15]$. Noteworthy, the encapsulation of Selol did not significantly affect its activity against A549 cells and reduced its toxicity toward normal cells. These results encourage further tests of Selol activity in in vivo models of pulmonary cancer. Moreover, some characteristics of the investigated nanocapsules point to their potential to act as good drug delivery systems. First, their hydrodynamic diameters can be tuned to values that allow for the passive targeting of tumors via an enhanced permeation and retention effect (EPR) because the tumor microvasculature usually presents pores with diameters of 100 to $780 \mathrm{~nm}$ [26]. Second, targeting molecules can be conjugated to the surface of nanocapsules to increase their affinity to cancerous cells. This procedure can be easily performed because PVM/MA has anhydride groups, which can easily react with the hydroxyl or primary amine groups present in most of the available targeting molecules [16].

Subsequent experiments with SS, S and SPN were performed with a concentration of $100 \mu \mathrm{g} / \mathrm{mL}$ Se because this was the lowest concentration in S and SPN treatments that reduced cell viability. Moreover, SPN was always used within 60 days after preparation because its biological activity did not significantly change during storage at $4^{\circ} \mathrm{C}$ for this period of time $(\mathrm{p}>0.05)$ (Figure 4).

SPN reduces cell proliferation and promotes cell cycle arrest As expected, both untreated normal and A549 cells proliferate in culture, as evidenced by the time-dependent increase in the number of cells $(\mathrm{p}<0.001$ for both $24 \mathrm{vs}$. $48 \mathrm{~h}$ and 48 vs. $72 \mathrm{~h}$ for A549; $\mathrm{p}<0.01$ for 24 vs. $48 \mathrm{~h}$, and $\mathrm{p}<0.05$ for 48 vs. $72 \mathrm{~h}$ for normal cells) (Figure 3

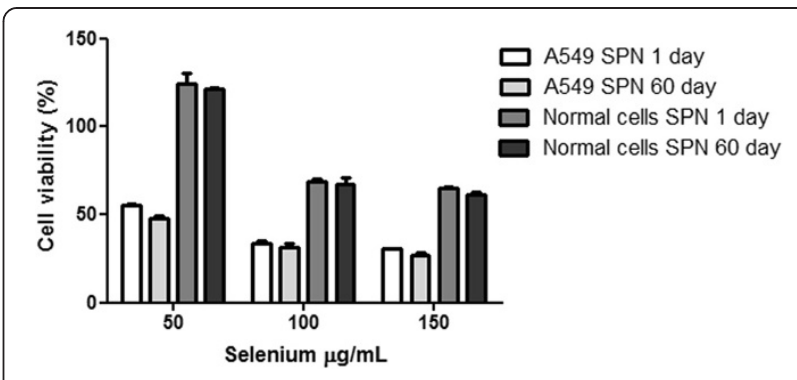

Figure 4 Viability of A549 and human connective tissue cells treated with Selol-PVM/MA nanocapsules (SPN) after 1 and 60 days of storage at $4^{\circ} \mathbf{C}$. The cells were treated with 50, 100 and $150 \mu \mathrm{g} / \mathrm{mL}$ Se for $72 \mathrm{~h}$, and the data are expressed as the means \pm standard error of the mean of the percentages of viable cells. No statistically significant difference was found between the results for SPN after 1 day and SPN for 60 days $(p>0.05)$.

(g and $\mathrm{h})$ ). SPN treatment inhibited the proliferation of both cell types, but the intensity of this effect was cell line-dependent. The number of both normal and tumor cells in the SPN-treated groups did not vary over the treatment time $(\mathrm{p}>0.05)$. Reductions of $40.4 \pm 2.7 \%$ and $64.7 \pm 1.7 \%$ in the number of SPN-treated A549 cells were evidenced at $48 \mathrm{~h}(\mathrm{p}<0.001)$ and $72 \mathrm{~h}(\mathrm{p}<0.001)$, respectively, relative to the control A549 cells. However, normal cells were affected to a lesser extent because a significant reduction in their number was observed only at $72 \mathrm{~h}(24.8 \pm 6.7 \%, \mathrm{p}<0.01)$ compared with the control normal cells.

The real-time cell index monitoring also showed changes in this parameter after the first hours of SPN treatment on A549 cells, which became more significant for higher concentrations and longer times of incubation (Figure 5). Cell growth was detected up to $20 \mathrm{~h}, 28 \mathrm{~h}$ and $56 \mathrm{~h}$ in the presence of SPN at $150 \mu \mathrm{g} / \mathrm{mL}, 100 \mu \mathrm{g} / \mathrm{mL}$ and $50 \mu \mathrm{g} / \mathrm{mL}$ concentrations, respectively. Over these times, the cell indexes remained constant and subsequently decreased. Similar to previous results, the cell index in the treatment with $100 \mu \mathrm{g} / \mathrm{mL}$ SPN was almost invariant at 24,48 , and $72 \mathrm{~h}$.

These results were corroborated by light microscopy images, which showed a more intense reduction in the confluence of SPN-treated A549 cells compared with SPN-treated normal cells (Figure 6). A549 cells treated with SPN presented a significantly higher proportion of cells arrested at the G2/M phase compared with that obtained for control cells (Table 2). These results are in good agreement with the decreases in the gene expression levels of CCNB1 (cyclin B1), CDC25C and WEE1 (FC (fold change) $>2.0$ ) and unchanged expression levels of the gene transcripts of CCND1 (cyclin D1) and CCNE1 (cyclin E1) $(\mathrm{FC}<2.0)$ (Figure $7(\mathrm{a})$ ), indicating that Selol acts on the G2/M arrest of the cell cycle and 


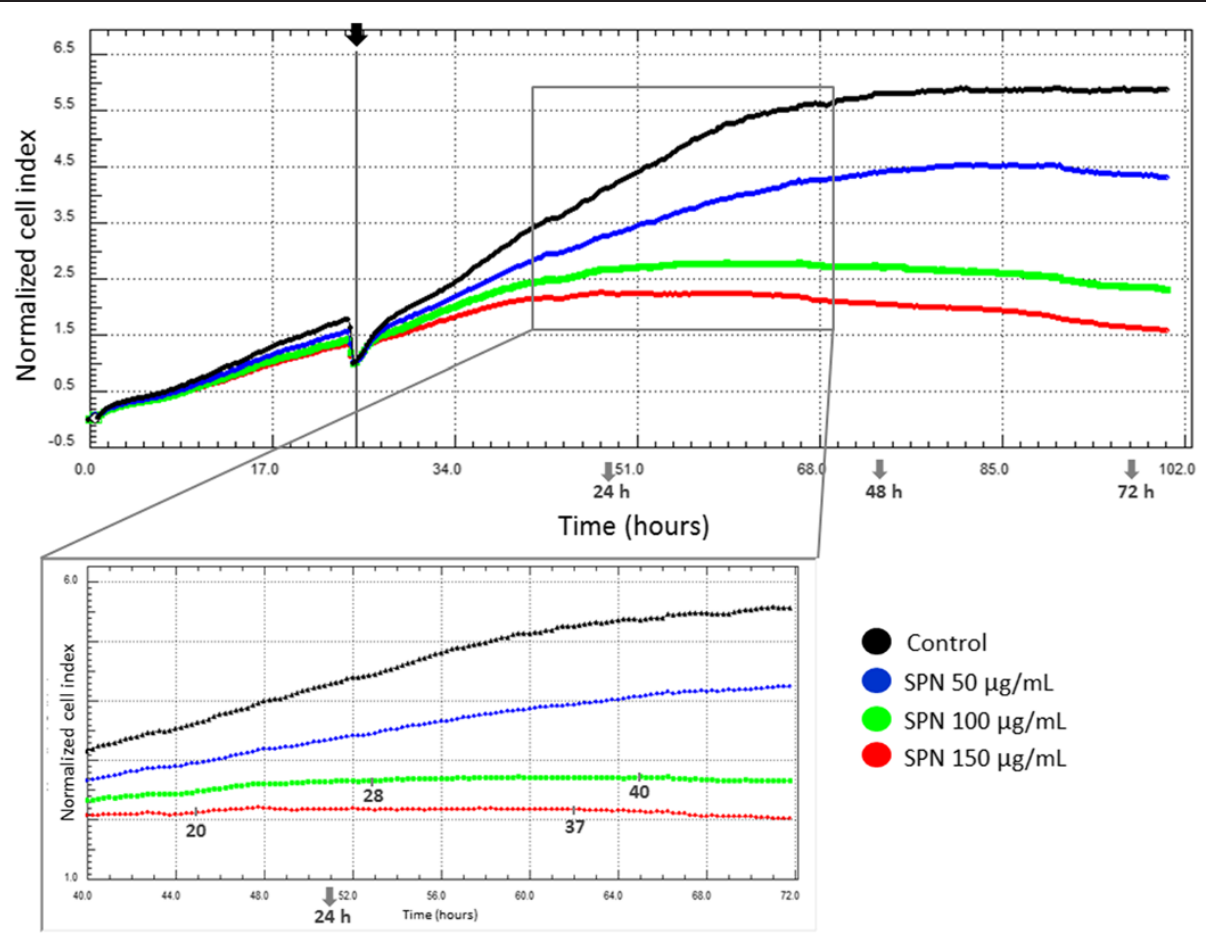

Figure 5 Real-time monitoring of cell indexes of A549 cells untreated (control) and treated with Selol-PVM/MA nanocapsules (SPN) at Se concentrations of 50,100 and $150 \mu \mathrm{g} / \mathrm{mL}$ for $100 \mathrm{~h}$. All of the treatments started $24 \mathrm{~h}$ after cell plating, as indicated by the vertical grey continuous line on the top panel. The bottom panel shows more detailed dynamic monitoring in the range of $15 \mathrm{~h}$ to $47 \mathrm{~h}$ after the treatment, and the time intervals with constant cell indexes are indicated on the bottom panel (values should be related to the treatment and not to the time after cell plating).

has no activity on the G1 and S checkpoints. In response to SPN treatment, the expression levels of CCNB1 and $\mathrm{CDC} 25 \mathrm{C}$ were reduced by half at $24 \mathrm{~h}$ and were markedly down-regulated after $48 \mathrm{~h}$ (approximately 17-fold for CCNB1 and 21-fold for CDC25C) and $72 \mathrm{~h}$ (approximately 25-fold for CCNB1 and 50-fold for CDC25C) compared with the control cells. The expression of WEE1 was reduced only to half at $48 \mathrm{~h}$ and $72 \mathrm{~h}$.

In relation to normal cells, A549 cells were more susceptible to Selol, both free and encapsulated, which may be partially due to enhanced endocytic activity [27]. Another possible explanation that is supported by the results of the present study is that tumor cells may be more sensitive to Selol due to their higher proliferation rates because Selol appears to primarily act as an inhibitor of cell proliferation. SPN significantly increased the percentage of A549 cells arrested in the G2/M phase of cell cycle and consequently reduced the number of living cells. In the G2 phase, the wee1 protein inactivates the mitosis promoting factor (cyclin $\mathrm{B} 1 / \mathrm{CDK} 1$ ), and $\operatorname{cdc} 25 \mathrm{C}$ is a positive regulator of this complex. As shown in previous studies, G2/M arrest may require activation of wee1 in addition to inactivation of cdc25C $[28,29]$.
Additionally, the decrease in cell proliferation induced by Selol was not associated with a decreased energy metabolism coordinated by the main mitochondrial deacetylase sirtuin 3 [30], as observed by the unchanged transcript levels of the SIRT3 gene $(\mathrm{FC}<2.0)$ (Figure 7(a)). Moreover, subtle changes in the expression of the $\beta$-actin gene (ACTB) in SPN-treated cells compared with untreated cells showed that this gene is not suitable as an endogenous control for SPN treatment (Figure 7(a)), likely due to association of the $\beta$-actin protein with cytoskeletal components and consequent cell division events [31].

\section{Morphological alterations}

Phase contrast microscopy revealed that neither SPN nor free Selol induced morphological changes in A549 cells. SPN treatment did not induce any morphological alterations in normal cells because most of them were shown to be spindle-shaped with cytoplasmic projections, as expected. In contrast, free Selol induced visible cytoplasmic retraction (arrows) in normal cells (Figure 6). Comparatively, pronounced morphological changes were induced by SS in both normal and A549 cells.

Some ultrastructural signs of cell death were observed in A549 cells after treatment with Selol. Mitochondrial 


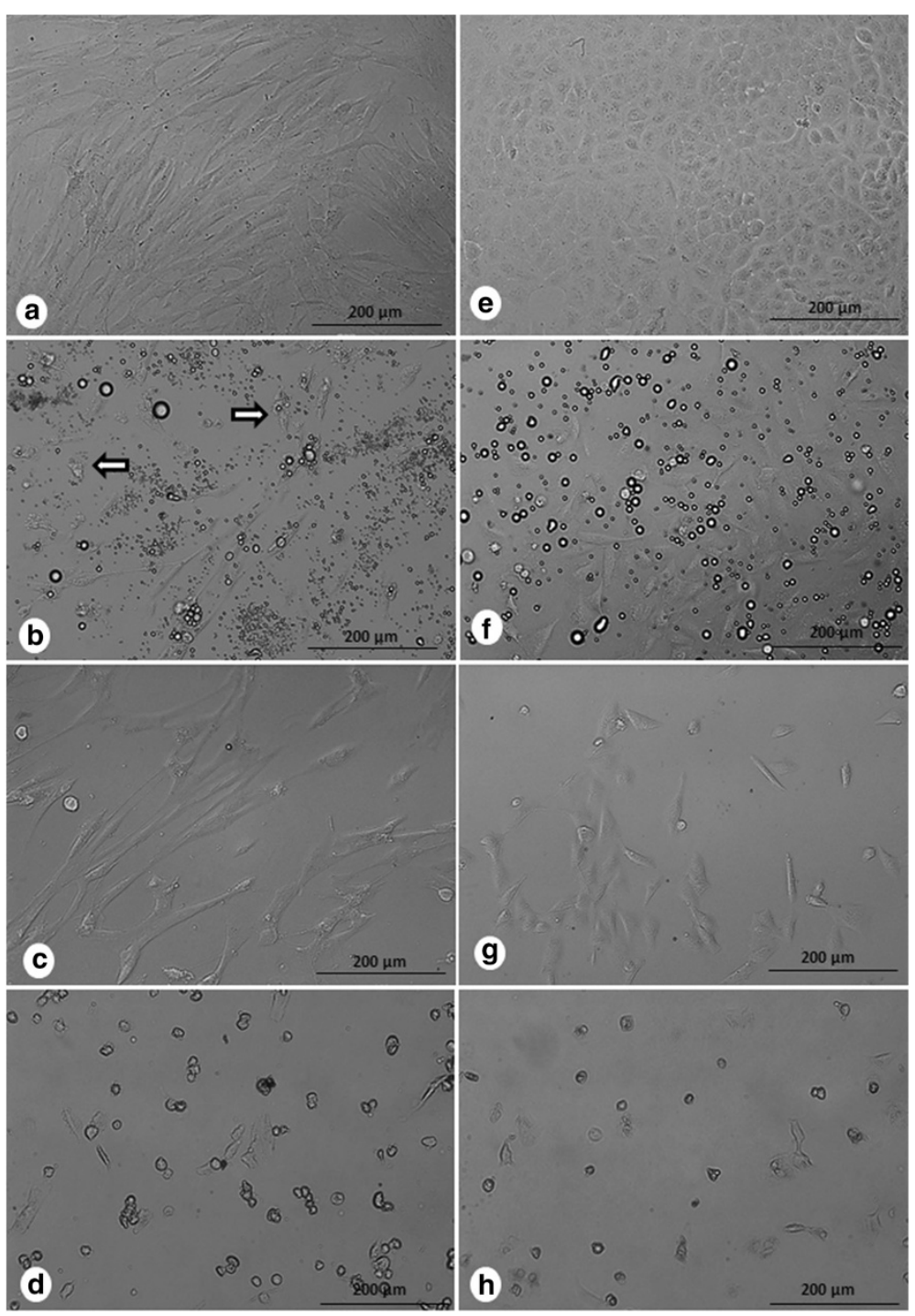

Figure 6 Morphology of human cells from connective tissue (a, b, c, d) and A549 cells (e, f, g, h). The cells were untreated (a, e), exposed to free Selol (S) (b, f) or to Selol-PVM/MA nanocapsules (SPN) (c, $\mathbf{g})$ for $72 \mathrm{~h}$. Morphologic changes due to sodium selenite (SS) treatment for $24 \mathbf{h}(\mathbf{d}, \mathbf{h})$. Decrease in cell confluence by S and SPN treatments. Normal morphology of A549 (f, $\mathbf{g})$ and SPN-treated connective tissue cells. Cytoplasmic retraction (arrows) on human cells from connective tissue after treatment with $\mathbf{S}$ (b). The bright, black-bordered spherical structures are free Selol microdroplets (b, f). Magnification: 20x.

Table 2 Effect of Selol-PVM/MA nanocapsule (SPN) treatment on the cell cycle distribution of A549 cells

\begin{tabular}{llll}
\hline A549 & G0/G1 (\%) & S (\%) & G2/M (\%) \\
\hline Control 48 h & $69.6 \pm 2.9$ & $18.4 \pm 2.3$ & $12.2 \pm 1.3$ \\
SPN 48 h & $56.6 \pm 3.8$ & $26.5 \pm 0.9$ & $16.9 \pm 3.7^{*}$ \\
Control 72 h & $70.7 \pm 3.9$ & $18.8 \pm 2.9$ & $10.6 \pm 1.7$ \\
SPN 72 h & $56.2 \pm 1.3$ & $25.0 \pm 1.9$ & $18.7 \pm 2.7^{*}$ \\
\hline
\end{tabular}

${ }^{*} p<0.05$ compared with the control. The data were obtained from three independent experiments and are presented as the means \pm standard error of the mean. changes and intense vacuolization were apparent (Figure 8). Additionally, cytoplasm swelling suggestive of necrosis was present. These morphological changes suggest that apoptosis and necrosis are induced by treatment with Selol. Most of the normal cells did not present any morphological changes after SPN treatment (Figure 9). However, the cells exposed to free Selol presented large endosomes containing Selol, whereas the SPN-treated cells did not present visible Selol particles. Endocytosis of free Selol droplets in both cell lines caused the compression of adjacent organelles. In addition, an unambiguous identification of Selol nanoparticles was not possible due to similarities with cellular lipids. 


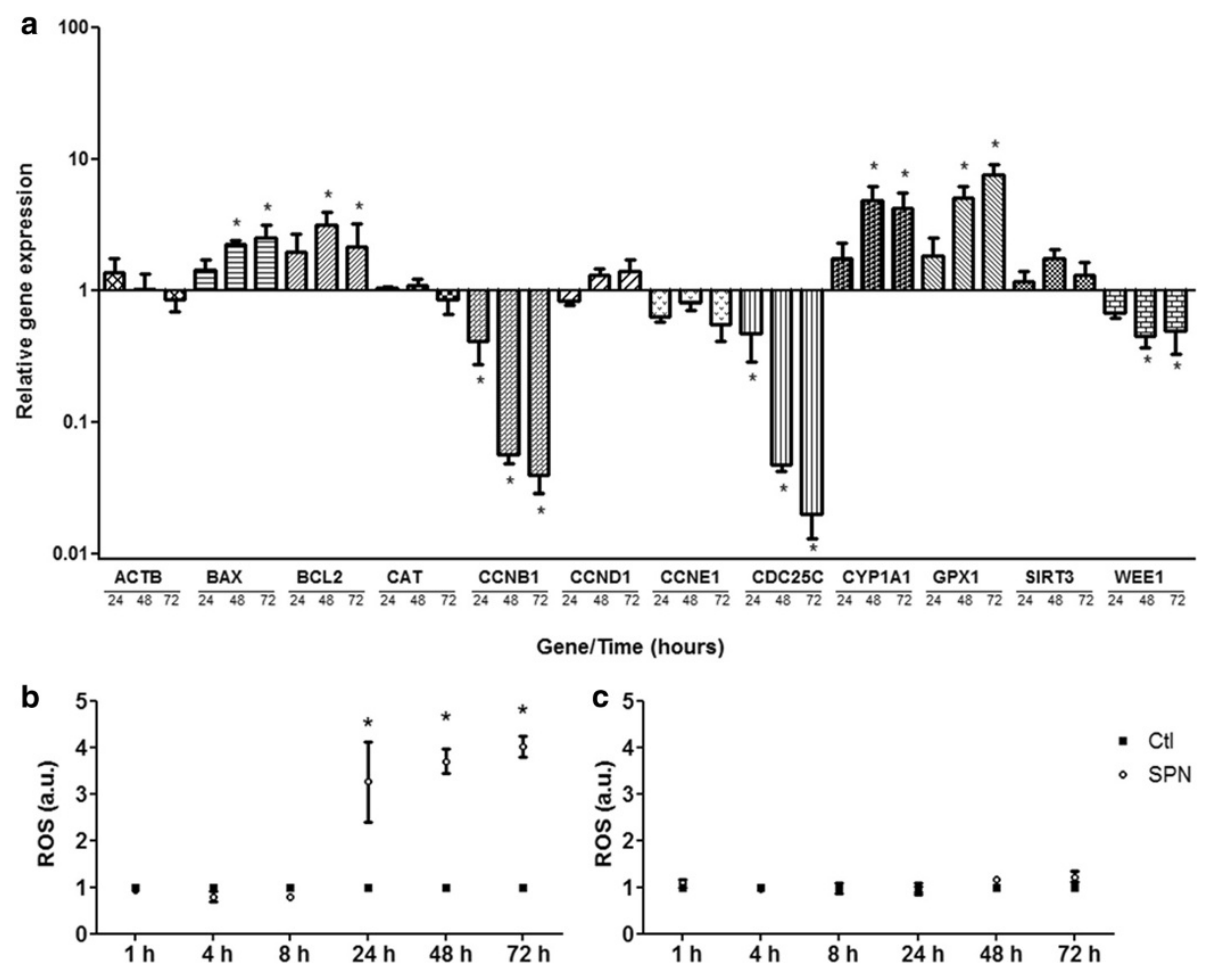

Figure 7 Relative gene expression of A549 cells treated with Selol-PVM/MA nanocapsules (SPN) at a concentration of $100 \mu \mathrm{g} / \mathrm{mL}$ for $\mathbf{2 4} \mathbf{h}, \mathbf{4 8} \mathbf{~ h}$ and $\mathbf{7 2} \mathbf{~ h}$ (a). The following genes were down-regulated: CCNB1, CDC25C and WEE1. The following genes were up-regulated: BCL2, BAX, GPX1 and CYP1A1. *FC > 2.0. Production of reactive oxygen species (ROS) in A549 (b) and HL60 (c) cells treated with SPN at a concentration of $100 \mathrm{\mu g} / \mathrm{mL}$ (SPN). SPN-treated samples were normalized according to the control samples (Ctl). The bars represent the means \pm standard error. ${ }^{*} p<0.001$.

\section{Cell death signaling}

$\mathrm{S}$ and SPN induced the exposure of phosphatidylserine on the outer leaflet of the plasma membrane and impairment of plasma membrane permeability only in a discrete percentage of A549 cells. After $72 \mathrm{~h}$ of exposure, only $11.2 \pm 0.6 \%$ $(\mathrm{p}<0.01)$ and $12.9 \pm 2.3 \%(\mathrm{p}<0.001)$ of A549 cells were propidium iodide (PI)- and/or annexin V-positives after $\mathrm{S}$ and SPN treatments, respectively. In control A549 cells, this percentage was $2.9 \pm 0.5 \%$ (Figure 10).

SPN treatment caused an increase in the percentage of A549 cells presenting reduced mitochondrial membrane potential $(\Delta \Psi m)$ compared with control cells at $48 \mathrm{~h}$ $(14.5 \pm 4.2 \%, \mathrm{p}<0.05)$ and $72 \mathrm{~h}(22.8 \pm 5.4 \%, \mathrm{p}<0.001)$ (Figure 11(a)). Figure 11(b) also shows the $\Delta \Psi m$ of control and SPN-treated A549 cells at $72 \mathrm{~h}$. These findings are compatible with the mitochondrial damages evidenced by ultrastructure analysis.

DNA fragmentation increased after $48 \mathrm{~h}(19.8 \pm 1.1 \%$ vs. $3.6 \pm 1.0 \%$ for control, $\mathrm{p}<0.001)$ and $72 \mathrm{~h}(24.0 \pm 2.5 \%$ vs. $4.6 \pm 1.0 \%$ for control, $\mathrm{p}<0.001)$ of SPN treatment (Figure 11(c)). As shown in Figure 11c, this treatment resulted in an increase in the sub-G1 cell population, a clear reduction in the percentage of cells in the G1 phase and an increase in the percentage of cells in the G2/M phase (Figure 11(d)).
The levels of transcripts related to apoptosis, namely BAX (BCL2-associated X protein) and BCL-2 (B-cell lymphoma 2), increased after $48 \mathrm{~h}$ (2-fold and 3-fold for BAX and BCL-2, respectively) and $72 \mathrm{~h}$ (2-fold for both BAX and BCL-2) (Figure 7(a)). These results suggest that Selol triggers damages that are able to activate the apoptosis mechanisms. However, the BAX/BCL2 ratio, which is recognized as an initiator of the caspases activation pathway, was slightly increased only at $72 \mathrm{~h}$. The results presented suggest that the mechanism of action of Selol in A549 cells is not crucially dependent on the direct induction of apoptosis or necrosis. Suchocki et al. (2007) [4] demonstrated mitochondrial changes and DNA fragmentation in a leukemia cell line, and Estevanato et al. (2012) [32] and Wilczynska et al. (2011) [25] observed the translocation of phosphatidylserine in breast and cervix cancer cell lines. In the present study, the exposition of phosphatidylserine, changes in the mitochondrial membrane potential, DNA fragmentation, and/or alterations in the plasma membrane permeability were observed in low percentages of A549 cells after treatment with free or encapsulated Selol. These findings, however, do not exclude the possibility that Selol may induce extensive A549 cell death at the highest concentrations and/or 


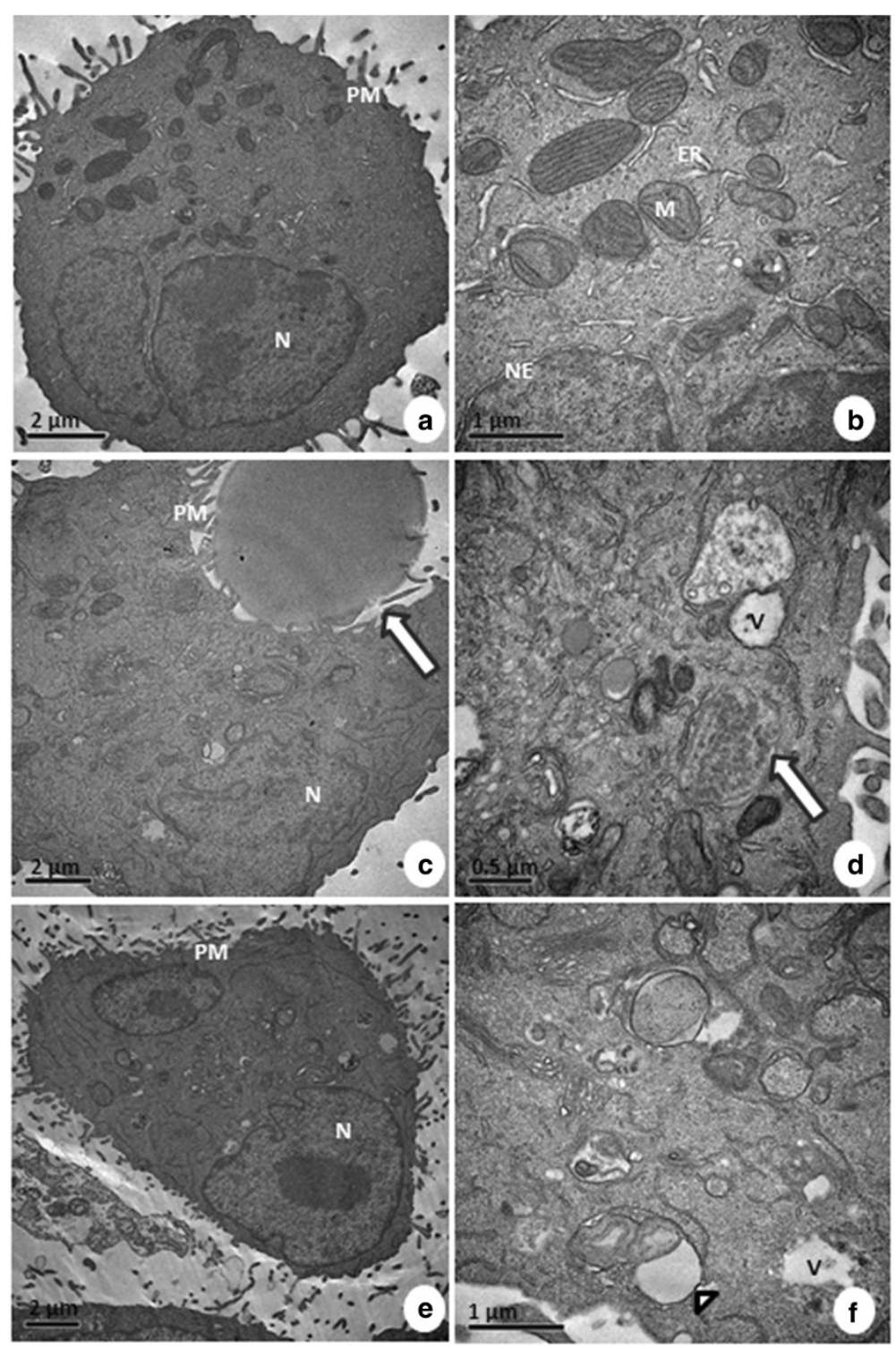

Figure 8 Ultrastructural morphology of A549 cells: control (a, b), treated with free Selol (S) (c, d) and treated with Selol-PVM/MA nanocapsules (SPN) (e, f). Note the integrity of the mitochondria (M), endoplasmic reticulum (ER), plasma membrane (PM), nucleus (N), nuclear envelope (NE), and cytosol of the control cells. An endocytosed Selol droplet is shown with an arrow in c. Endosomes, as indicated by an arrow in $\mathbf{d}$, were usually identified with the free Selol treatment. Cytoplasm characteristic of necrotic cells can be observed in e (arrow). Intense formation of vacuoles $(V)$ containing cellular organelles and changes in the morphology of mitochondria (arrowhead) can be evidenced in $\mathbf{d}$ and $\mathbf{f}$

after prolonged treatment times. Prolonged cell cycle arrest may elicit apoptosis insomuch that cell death may not only be due to primary damage but also result from accumulation of damages arising from the cell cycle arrest itself [33].

\section{Oxidative stress in A549 cells}

The production of reactive oxygen species (ROS) was evaluated in A549 cells compared with HL60 promyelocytic cells. The HL60 cell line is a cell model that is frequently used to access the oxidant or antioxidant potential of different compounds [34,35]. In the current study, Selol surprisingly did not induce an oxidative burst on HL60 cells (Figure 7(b)). Otherwise, ROS accumulation was observed in A549 cells at higher SPN exposure times (24, 48 and $72 \mathrm{~h}$ ) (Figure $7(\mathrm{~b})$ ). These findings suggest that the SPN-induced oxidative burst is variable according to the cell type.

Additionally, increased expression of GPX1 (glutathione peroxidase 1) (5-fold and 7-fold at $48 \mathrm{~h}$ and $72 \mathrm{~h}$, 

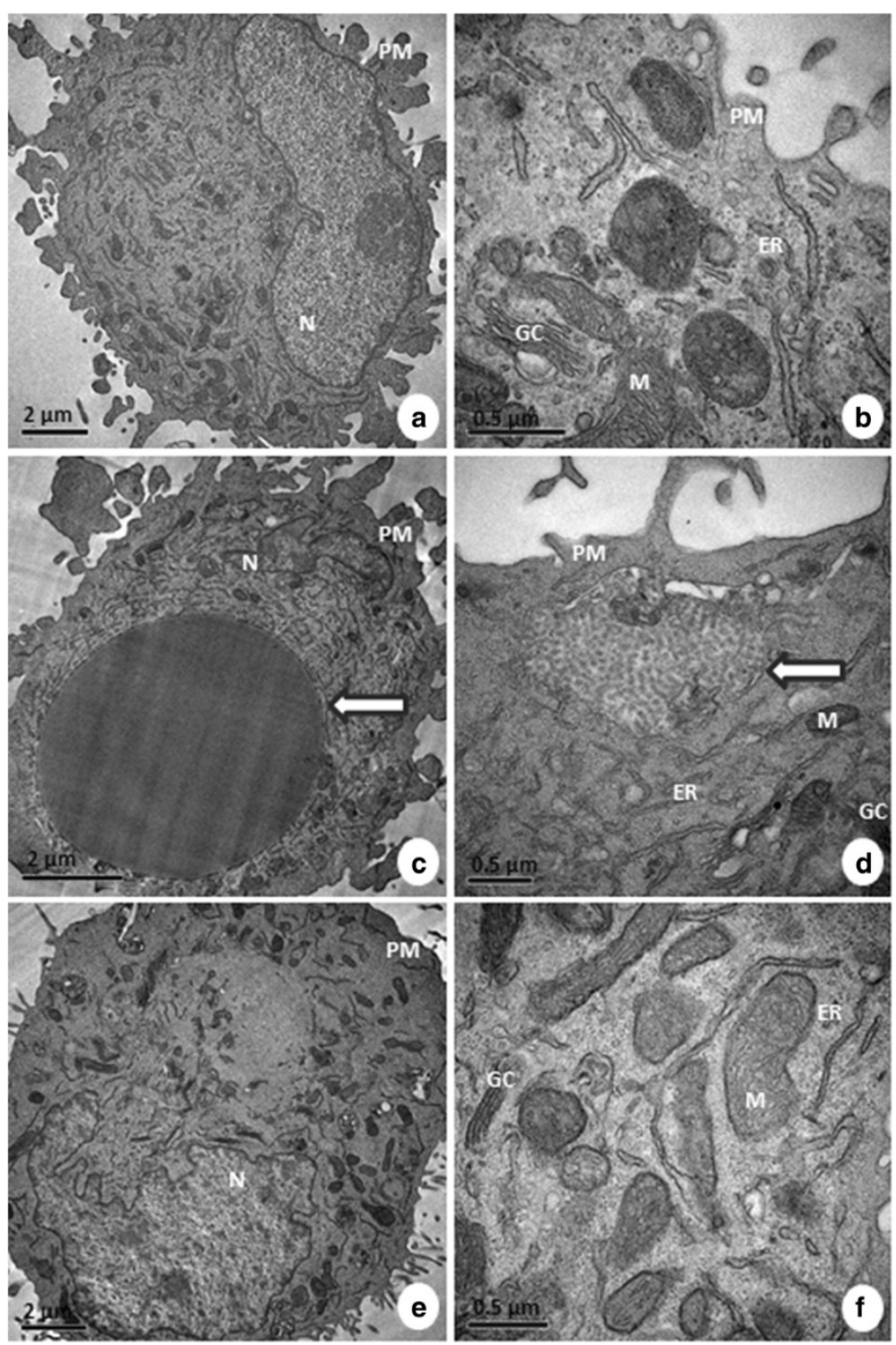

Figure 9 Ultrastructural morphology of human connective tissue cells: control $(a, b)$, treated with free Selol (S) (c, d) or treated with Selol-PVM/MA nanocapsules (SPN) (e, f). Note the integrity of the control cells, as expected. In $\mathbf{c}$, a Selol vesicle being taken up by a cell exposed to free Selol is shown by an arrow. In $\mathbf{d}$, the arrow points to an endosome. In $\mathbf{e}$ and $\mathbf{f}$, the ultrastructural morphology is unchanged by SPN treatment. N, M, ER, GC, PM, and V: nucleus, mitochondria, endoplasmic reticulum, Golgi complex, plasma membrane and vesicle, respectively.

respectively) was evidenced on A549 cells (Figure 7(a)). Increased levels of ROS coincident with the upregulation of GPX1 indicate that A549 cells responded in response to exposure to SPN by activation of the antioxidant defense systems. Suchocki et al. (2010) [5] showed the involvement of ROS and the inhibition of CYP1A1 (cytochrome P450) induced by Selol in cervix cancer cell lines. Conversely, in this study, the expression of CYP1A1 (4-fold on both $48 \mathrm{~h}$ and $72 \mathrm{~h}$ ) on A549 cells was enhanced by SPN treatment (Figure 7(a)). The metabolism and detoxification of xenobiotics performed by cytochrome $\mathrm{P} 450$ may be associated with SPN metabolism and ROS generation [36]. Therefore, the present study suggests that ROS production on A549 cells may be associated with cell death and inhibition of proliferation, as evidenced by Chen et al. (2013) [37].

Despite the induction of oxidative stress observed on A549 cells, SPN had no effect on the gene expression of catalase at the concentration and times evaluated (Figure 7(b)), corroborating the results of a study on prostate cancer cells treated with Selol for 24 and $48 \mathrm{~h}$ [38]. 

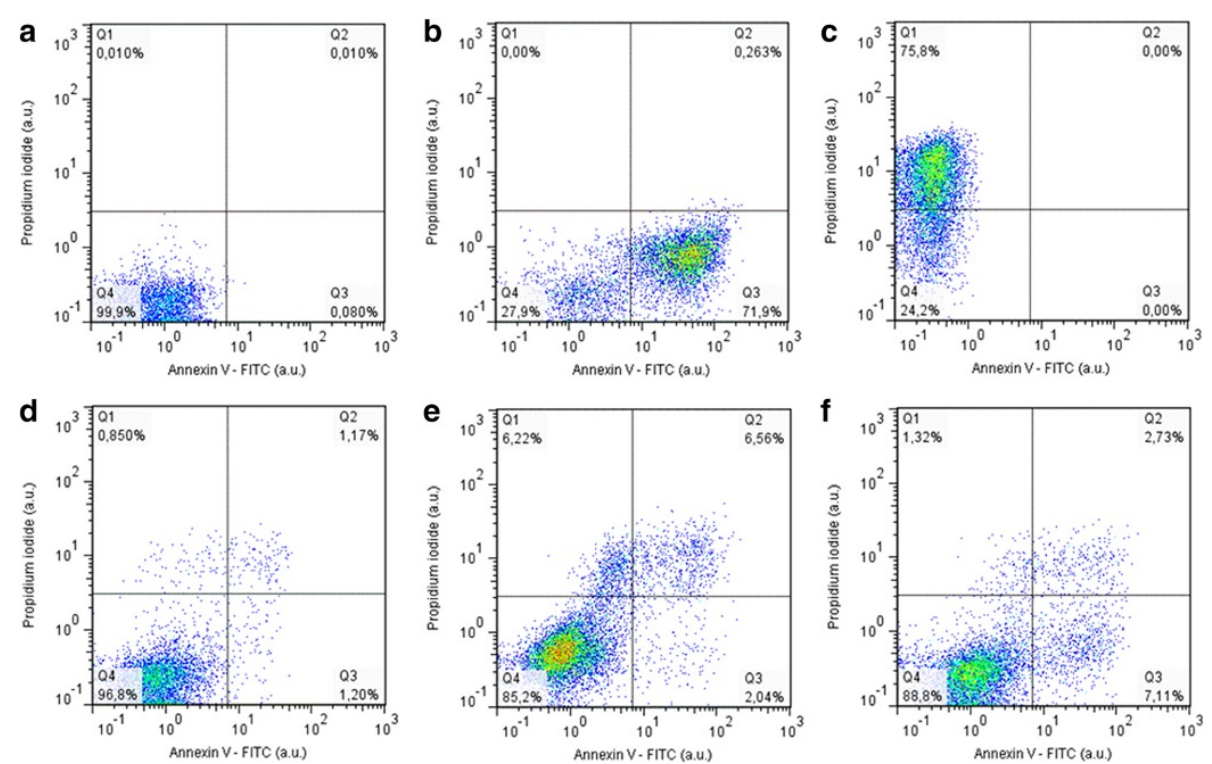

Figure 10 Influence of free Selol (S) or Selol-PVM/MA nanocapsules (SPN) on A549 cells. Flow cytometry study of cells stained with propidium iodide (PI) and/or annexin V-FITC. The positive cells are shown as percentages in each quadrant: $\mathrm{Pl}^{+}(\mathrm{Q} 1), \mathrm{Annexin}^{+}(\mathrm{Q} 3)$, double-negative $\mathrm{Pl}^{-}$Annexin $\mathrm{V}^{-}(\mathrm{Q} 4)$, and double-positive cells $\mathrm{Pl}^{+}$Annexin $\mathrm{V}^{+}(\mathrm{Q} 2)$. Negative control (a). Annexin $\mathrm{V}^{+}$control (b). $\mathrm{Pl}^{+}$control (c). Untreated cells (d). Similar membrane integrity was observed after S (e) and SPN (f) treatments.
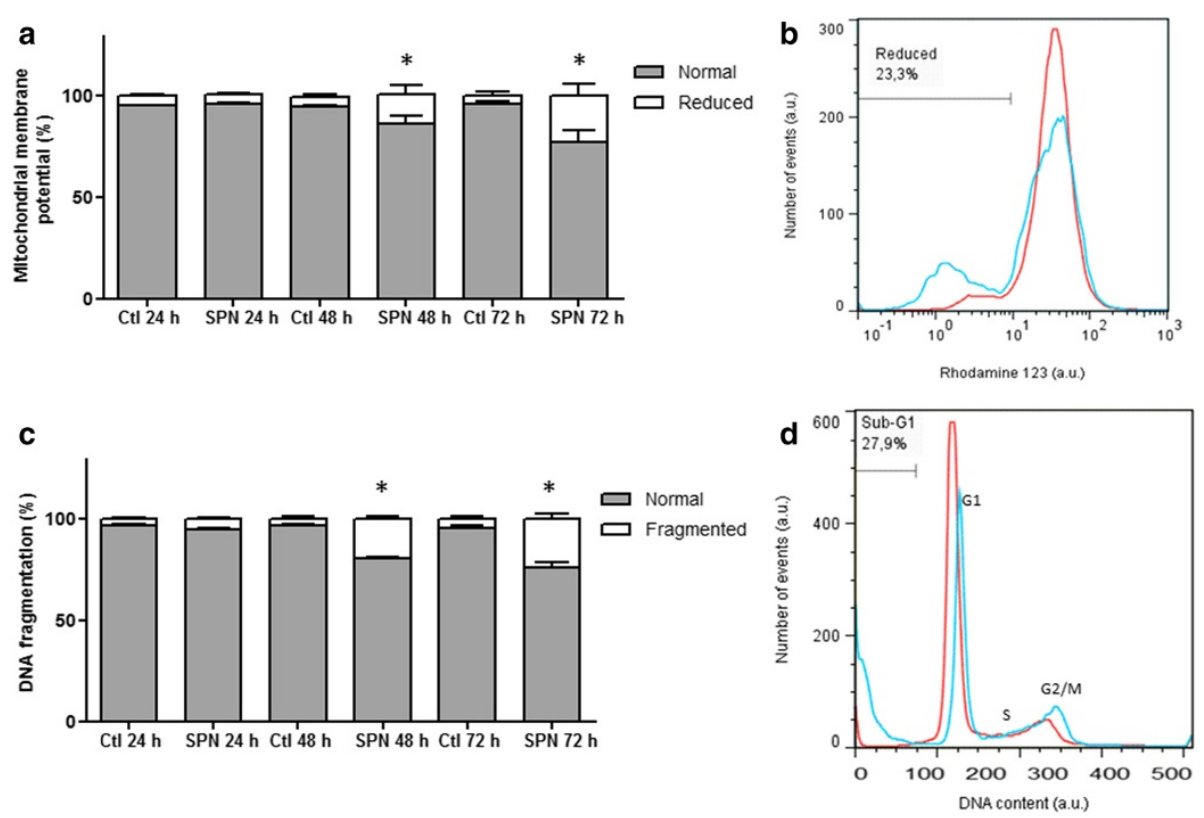

Figure 11 Mitochondrial membrane potential and by DNA fragmentation of A549 cells treated with selol-PVM/MA nanocapsules (SPN) and untreated cell (control cells, Ctl) at different times. ${ }^{*} p<0.05$ for Ctl $48 \mathrm{~h}$ vs. SPN $48 \mathrm{~h} ; \mathrm{p}<0.001$ for Ctl $72 \mathrm{~h}$ vs. SPN $72 \mathrm{~h}$ (a). Representative histogram showing a sample of control cells (red line) and a sample of SPN-treated cells (blue line) after $72 \mathrm{~h}$ (b). DNA fragmentation in SPN-treated or untreated A549 cells at different times. ${ }^{*} \mathrm{p}<0.001$ for Ctl $48 \mathrm{~h}$ vs. SPN $48 \mathrm{~h} ; \mathrm{p}<0.001$ for Ctl $72 \mathrm{~h}$ vs. SPN $72 \mathrm{~h}$ (c). Representative histogram showing sub-G1 (DNA fragmented), G1, S and G2/M populations for Ctl (red line) and SPN-treated cells (blue line) after $72 \mathrm{~h}$ (d). 


\section{Conclusions}

This study demonstrates that Selol can act as a cytostatic agent and corroborates previous reports indicating that it is effective against cancerous cells and safer for clinical applications than sodium selenite. Furthermore, the present study includes the development of a stable and monodisperse aqueous vehicle for Selol delivery, namely PVM/MA-shelled Selol nanocapsules, which are able to maintain the activity of free Selol against pulmonary adenocarcinoma cells, exhibit reduced toxicity to nontumor cells in vitro and are thus potentially suitable for the treatment of some types of lung cancer. Further in vivo studies should be performed to evaluate the potential of this formulation for human therapy.

\section{Methods}

\section{Materials}

Selol composed of 5\% selenium (w:w) was provided by Warsaw Medical University (Poland). PVM/MA (Gantrez AN 119) was kindly gifted by ISP Corp. (Brazil). Human lung adenocarcinoma (A549) and promyelocytic leukemia (HL60) cell lines were purchased from American Type Culture Collection (USA). Sodium selenite, trifluoroacetic acid, dimethyl sulfoxide and rhodamine 123 were purchased from Sigma (USA). Dulbecco's modified Eagle's medium, F12 medium, Roswell Park Memorial Institute medium, 3,4,5-dimethylthiazol-2,5 biphenyl tetrazolium bromide (MTT), annexin V-FITC and propidium iodide (PI) were provided by Invitrogen (USA). Fetal bovine serum, penicillin and streptomycin were purchased from Gibco (USA). RNase A was obtained from Promega (USA). Primers and 2',7'-dichlorodihydrofluorescein diacetate (DCFH-DA) were acquired from Life Technology (USA). Phorbol 12-myristate 13-acetate (PMA) was obtained from Abcam (England). GeneJet RNA purification and cDNA Maxima kits were provided by Life Science (USA). DNase I, free-RNase kit was purchased from Thermo Scientific (USA). The TaqMan gene expression assay was obtained from AB Applied Biosystems (USA). Grids and supports of copper and osmium tetroxide were obtained from Electron Microscopy Sciences (USA). Dichloromethane was purchased from Vetec (Brazil). Ethanol and acetone were purchased from J. T. Baker (USA). Phosphate buffer saline was obtained from Laborclin (Brazil).

\section{Preparation of nanocapsules}

Nanocapsules were prepared through an interfacial nanoprecipitation method. Briefly, Selol (oil phase) and PVM/ MA (surfactant) were dissolved in acetone at room temperature (RT). Next, ethanol and distilled water were sequentially added to the acetone solution, under mild stirring, to form a yellowish, opaque suspension. The organic solvents were removed by distillation at $45^{\circ} \mathrm{C}$ under reduced pressure $(80 \mathrm{mbar})$ in a rotavapor apparatus (Rotavapor
$\mathrm{RII}^{\oplus}$, Buchi Switzerland). Next, the resulting oily nanocapsules were centrifuged at $22,000 \times g$ for $30 \mathrm{~min}$, the transparent aqueous supernatant was removed, and the pellet was resuspended in distilled water. This preparation was immediately characterized and/or stored at $4^{\circ} \mathrm{C}$ until usage.

\section{Colloidal characterization}

The nanocapsules were dispersed in phosphate buffer saline (PBS) (pH 7.4) at a concentration of Selol equivalent to $100 \mu \mathrm{g} / \mathrm{mL}$. Then, the hydrodynamic diameter (HD) and polydispersity index (PDI) and the zeta potential ( $\zeta$ potential) were measured at $25^{\circ} \mathrm{C}$ by dynamic light scattering (DLS) and electrophoretic laser Doppler anemometry (ZetaSizer Nano ZS ${ }^{\oplus}$, Malvern Instruments), respectively.

\section{Surface morphology and structure}

The shape and surface morphology of the capsules were investigated using a field emission scanning electron microscope (SEM) (JEOL JSM 7001-F, Japan). Before analysis, the composition was diluted with ultrapure water to $5 \%$ (v:v), and $20 \mu \mathrm{L}$ was deposited onto copper supports. Next, the sample was fixed with $1 \%$ osmium tetroxide vapor (w:v) for $1 \mathrm{~h}$, left to dry at RT and coated with gold using a Blazers SCD $050^{\circ}$ sputter coater (Blazers Union AG, Liechtenstein). The images were digitized using an UltraScan ${ }^{\circ}$ camera connected to the Digital Micrograph $^{\circledast}$ 3.6.5 computer software (Gatan, USA).

The diameter values of 300 nanocapsules were measured with the Image Pro-Plus ${ }^{\oplus} 5.1$ software from images captured with a transmission electron microscope (TEM) (JEOL JEM 1011 ${ }^{\circ}$, Japan). Before this analysis, the sample was diluted with ultrapure water to $3 \%(\mathrm{v}: \mathrm{v})$ and deposited onto a copper grid. The dried sample was fixed and contrasted with $1 \%$ osmium tetroxide vapor (w:v) for $20 \mathrm{~min}$. The images were digitized using an UltraScan ${ }^{\odot}$ camera connected to the Digital Micrograph 3.6.5 ${ }^{\circ}$ computer software (Gatan, USA).

\section{Efficiency of Selol encapsulation}

The Selol concentration in the nanocapsules was estimated according to Suchocki et al. (2003) [39]. Briefly, $300 \mu \mathrm{L}$ of the nanocapsules dispersion was centrifuged at $22,000 \times g$ and $4^{\circ} \mathrm{C}$ for $30 \mathrm{~min}$. The pellet was left to dry at RT for two days. Next, Selol was extracted from the pellet with $800 \mu \mathrm{L}$ of dichloromethane and oxidized with $200 \mu \mathrm{L}$ of trifluoroacetic acid. The selenium absorbance was measured at a wavelength of $380 \mathrm{~nm}$ in a quartz cuvette. The efficiency of Selol encapsulation was calculated considering the ratio of the encapsulated mass to the mass of Selol that was initially used.

\section{Thermodynamic stability studies}

Storage at room temperature, $4^{\circ} \mathrm{C}$ and $-20^{\circ} \mathrm{C}$. Aliquots of the nanocapsule dispersion were stored at $\mathrm{RT}, 4^{\circ} \mathrm{C}$ or $-20^{\circ} \mathrm{C}$, 
and their colloidal characteristics (HD, PDI and $\zeta$ potential) were evaluated every 15 days.

Freezing and thawing cycles. Fifteen cycles of freezing $\left(-20^{\circ} \mathrm{C}\right)$ and thawing $\left(25^{\circ} \mathrm{C}\right)$ were applied to a nanocapsule aliquot. After each cycle, the HD, PDI and $\zeta$ potential were evaluated.

\section{Cell culture}

The A549 human lung adenocarcinoma cell line was cultured with a 1:1 (v:v) mixture of Dulbecco's modified Eagle's medium (DMEM) and F12 medium supplemented with $10 \%$ (v:v) fetal bovine serum (FBS) and 1\% (v:v) antibiotic solution (100 units $/ \mathrm{mL}$ penicillin and $100 \mathrm{mg} / \mathrm{mL}$ streptomycin). Human connective tissue cells harvested from the dental pulp of normal teeth were maintained in primary culture and used as non-tumor control cells, namely normal cells [40]. These cells were grown in DMEM supplemented with $10 \%$ FBS and $1 \%$ antibiotic solution, as described above. Both cells were maintained at $37^{\circ} \mathrm{C}$ in a $5 \% \mathrm{CO}_{2}$ and $80 \%$ humidity environment.

\section{Treatment design}

The cells were allowed to adhere to culture microplates for $24 \mathrm{~h}$ and were then treated as follows: (1) SelolPVM/MA nanocapsules (SPN), (2) free Selol (S), (3) blank polymeric nanoparticles without Selol (Bl), and (4) sodium selenite (SS). Cells treated with culture medium, culture medium/acetone and culture medium/ PBS corresponded to the control groups of SPN, S and SS, respectively. For the free Selol treatments, Selol was dissolved in acetone and then added to the culture medium, as described by Suchocki et al. (2007) [4]. Before the tests, a viability study was performed to ensure that the volumes of acetone required for each Selol concentration would not be cytotoxic themselves. Bl nanoparticles were prepared using the same method with the same concentrations of the components used for SPN but without Selol. Each treatment was performed in triplicate with different Se concentrations $(50,100$ and $150 \mu \mathrm{g} / \mathrm{mL})$ and times of exposure $(24,48$ and $72 \mathrm{~h}$ ). The concentration of PVM/MA in the treatments with $\mathrm{Bl}$ was equivalent to that used in the SPN treatment.

To verify whether the biological activity of SPN was maintained during storage at $4^{\circ} \mathrm{C}$, the cell viability was also evaluated on days $1^{\text {st }}$ and $60^{\text {th }}$ after preparation of the SPN.

\section{Cell viability}

The cells were seeded and treated as described above. Next, the cells were incubated with $0.5 \mathrm{mg} / \mathrm{mL}$ MTT for $2.5 \mathrm{~h}$. The MTT solution was removed, and formazan was extracted from the cells with dimethyl sulfoxide [41]. The absorbance at a wavelength of $595 \mathrm{~nm}$ was measured using a spectrophotometer (Spectramax M2,
USA) and was used as an index of cell viability. The results were expressed as percentages relative to the control groups after $24 \mathrm{~h}$ of treatment.

\section{Cell counting}

A549 and normal cells were treated with SPN $(100 \mu \mathrm{g} / \mathrm{mL})$ for 24, 48 and $72 \mathrm{~h}$. Next, the cells were harvested and quantified using a Scepter ${ }^{\text {rum }}$ Cell Counter (Millipore, USA).

\section{Morphology and confluence of cells}

The morphology and confluence of the cells were analyzed using a phase contrast microscope (Zeiss, Germany) and the AxioVision ${ }^{\circ}$ software (Zeiss, Germany). For ultrastructural analysis, the cells were fixed, contrasted and dehydrated in agreement with the method described by Carneiro et al. (2011) [42]. Ultrathin sections were observed through TEM, and the images were digitized.

\section{Real-time cell index}

Real-time cell analysis was performed with a RTCA instrument (xCelligence, Roche, Switzerland) [43]. Briefly, A549 cells were seeded for $24 \mathrm{~h}$ on plates containing microelectronic sensor arrays and later incubated with medium or treated with different concentrations of SPN $(50,100$, and $150 \mu \mathrm{g} / \mathrm{mL})$. The cells were automatically monitored every $15 \mathrm{~min}$ for up to $100 \mathrm{~h}$. Two independent experiments were performed.

\section{Reactive oxygen species}

The intracellular production of reactive oxygen species (ROS) was measured using 2',7'-dichlorodihydrofluorescein diacetate (DCFH-DA) as an oxidation-sensitive fluorescent probe. The ROS production was evaluated in A549 and HL60 cells [34,35]. The HL60 cells were cultured in RPMI (Roswell Park Memorial Institute medium) supplemented with $10 \%$ FBS and $1 \%$ antibiotic solution and were maintained at $37^{\circ} \mathrm{C}, 5 \% \mathrm{CO}_{2}$ and $80 \%$ humidity. Then, the cells treated or not treated with SPN $(100 \mu \mathrm{g} / \mathrm{mL})$ for different times $(1,4,8,24,48$ and $72 \mathrm{~h}$ ) were stained with $2.5 \mu \mathrm{M}$ DCFH-DA for $30 \mathrm{~min}$ at $37^{\circ} \mathrm{C}$. HL60 cells treated with $10 \mathrm{mM}$ phorbol 12-myristate 13-acetate (PMA) were used as a positive control. A total of 10,000 events per sample were analyzed using a $\mathrm{FC}^{\circ} 00^{\circ}$ cytometer (Beckman Coulter, USA) and the FlowJo 7.6.3 software.

\section{Annexin V-FITC/propidium iodide staining}

The externalization of phosphatidylserine and the loss of plasma membrane integrity, which are signs of apoptosis and necrosis, respectively, were assessed with a doublestaining kit consisting of FITC-labeled annexin V and propidium iodide (PI). The cells were incubated with $100 \mu \mathrm{L}$ of binding buffer containing $10 \mathrm{mM} \mathrm{HEPES} / \mathrm{NaOH}$ (pH 7.4), $140 \mathrm{mM} \mathrm{NaCl}$ and $2.5 \mathrm{mM} \mathrm{CaCl} 2$. Next, $5 \mu \mathrm{L}$ of 
annexin V-FITC and $10 \mu \mathrm{L}$ of PI $(50 \mu \mathrm{g} / \mathrm{mL})$ were added, and the cells were incubated for $15 \mathrm{~min}$ in the dark at RT. The cells were analyzed with a CyFlow space cytometer (Partec, Germany), and 10,000 events were counted per sample. Cells not incubated with Annexin V-FITC and PI were used as the negative control. Cells incubated with $100 \mu \mathrm{g} / \mathrm{mL}$ SS for 24,48 and $72 \mathrm{~h}$ were used as annexin V staining-positive cells. Cells killed by heating at $60^{\circ} \mathrm{C}$ for 5 min were used as PI staining-positive cells. All of the cytometry results reported in the CyFlow space were analyzed using the Windows ${ }^{\mathrm{Tm}}$ Flow $\mathrm{Max}^{\circ}$ and FlowJo 7.6.3 software programs.

\section{DNA fragmentation and cell cycle analysis}

The cell cycle was evaluated by the quantification of total DNA. A549 cells were fixed with 70\% ethanol for $2 \mathrm{~h}$ at $4^{\circ} \mathrm{C}$, rinsed with $\mathrm{PBS}$, incubated with $50 \mu \mathrm{g} / \mathrm{mL}$ RNase A for $30 \mathrm{~min}$ at $37^{\circ} \mathrm{C}$ and stained with $50 \mu \mathrm{g} / \mathrm{mL}$ PI for $30 \mathrm{~min}$ at RT [44]. A total of 10,000 events per sample were counted with a CyFlow ${ }^{\circ}$ cytometer, and the percentage of cells in different phases of the cell cycle was determined. Only those cells presenting DNA content in the range of $2 n-4 n$ were considered in the cell cycle analysis. Fragmented DNA was identified in the sub-G1 (DNA content $<2$ n) population and calculated considering the totality of events.

\section{Mitochondrial membrane potential}

The fluorescent cationic substrate rhodamine 123 (Rho123) was used to assess the mitochondrial membrane potential $(\Delta \Psi m)$ in A549 cells. The cells were incubated with $5 \mu \mathrm{g} / \mathrm{mL}$ Rho123 for $15 \mathrm{~min}$ at RT and washed twice with PBS [45]. A total of 10,000 events were analyzed per sample using a CyFlow ${ }^{\circ}$ cytometer.

\section{Quantitative RT-PCR (qRT-PCR)}

A549 cells were harvested after SPN treatment $(100 \mu \mathrm{g} / \mathrm{mL})$ for 24, 48 and $72 \mathrm{~h}$. The total RNA was extracted using a GeneJet RNA purification kit and was then treated with DNase I, free-RNase kit. cDNA was synthesized from mRNA using cDNA Maxima reverse transcription reagents. qRT-PCR was performed using a TaqMan gene expression assay, and the amplification reactions were performed using a Fast Real-time System 7900HT (Applied BioSystems, USA). The following primers (and their specifications) were used: АCTB (Hs99999903 m1), BAX (Hs00180269_m1), BCL2 (Hs00608023_m1), CAT (Hs00156308_m1), CDC25C (Hs00156411_m1), CC NB1 (Hs01030099_m1), CCND1 (Hs00765553_m1), CCN E1 (Hs01026536_m1), CYP1A1 (Hs00153120_m1), GAP DH (Hs02758991_g1), GPX1 (Hs00829989_gH), SIRT3 (Hs00953477_m1), and WEE1 (Hs00268721_m1). All of the kits were used according to the manufacturer's instructions.
The cDNA dilutions were defined based on threshold cycles $(\mathrm{CT})(17-20)$ derived from the amplification of the constitutive gene GAPDH $\left(R^{2} \geq 0.9974\right)$. Each sample was normalized based on the mRNA expression level of GAPDH. The gene expression values were obtained using the $2^{-\triangle \Delta C T}$ equation. A gene was considered to be differentially expressed when the transcript rate (FC, fold change) was at changed by at least twofold compared with the untreated control sample [46].

\section{Statistical analysis}

All of the experiments were performed in triplicate and repeated three times. The results are represented as the means \pm standard deviation. Significant differences were assessed by one- or two-way analyses of variance followed by Tukey or Bonferroni's post-tests $(\alpha=0.05)$ using the GraphPad Prism 5.0 software.

\section{Competing interests}

We confirm that we have given due consideration to the protection of intellectual property associated with this work and that there are no impediments to publication, including the timing of publication, with respect to intellectual property. The authors disclose no potential conflicts of interest.

\section{Authors' contributions}

LRS was the principal investigator and took primary responsibility for the paper. LRS, LAM, RBA and SNB participated in the design and coordination of the study. EM and PS conducted the Selol development. LAM, RG and PCM developed and characterized the Selol nanocapsules. LRS, MSCS, RS and GAJ performed the biological assays. AG participated in the coordination of some experiments and helped draft the manuscript. LRS, LAM, RBA and SNB wrote the manuscript and all of the authors helped discuss the results, adding thoughtful insights to the manuscript, and approved the final manuscript.

\section{Acknowledgments}

This work was supported by the Conselho Nacional de Desenvolvimento Científico e Tecnológico (CNPq), the Coordenação de Aperfeiçoamento de Pessoal de Nível Superior (CAPES), the Financiadora de Estudos e Projetos (FINEP), the Fundação de Empreendimentos Científicos e Tecnológicos (FINATEC), the Instituto Nacional de Ciência e Tecnologia (INCT), the European Union Seventh Framework Programme [FP7/REGPOT-2012-2013.1] under grant agreement BIOCAPS-316265 and Xunta de Galicia (INBIOMED 2012/273, DXPCTSUG-FEDER), and the National Science Centre in Poland (Grants N N405 360639 and N N202 166440).

\section{Author details}

${ }^{1}$ Institute of Biological Sciences, Molecular Biology Programme, University of Brasília, Brasília, DF 70910-900, Brazil. ${ }^{2}$ Institute of Biological Sciences, University of Brasília, Brasília, DF 70910-900, Brazil. ${ }^{3}$ Biomedical Research Center (CINBIO), Institute of Biomedical Research of Vigo, University of Vigo, Vigo, Pontevedra 36310, Spain. ${ }^{4}$ Institute of Physics, Polish Academy of Sciences, Warsaw 02-668, Poland. ${ }^{5}$ Department of Bioanalysis and Drugs Analysis, Warsaw Medical University, Warsaw 02-097, Poland. ${ }^{6}$ Department of Pharmaceutical Chemistry, National Medicines Institute, Warsaw 00-725, Poland. ${ }^{7}$ Institute of Physics, University of Brasília, Brasília, DF 70910-900, Brazil. ${ }^{8}$ School of Automation, Huazhong University of Science and Technology, Wuhan, Hubei 430074, China.

Received: 24 June 2014 Accepted: 12 August 2014 Published: 23 August 2014

\section{References}

1. El-Bayoumy K, Sinha R: Molecular chemoprevention by selenium: a genomic approach. Mutat Res 2005, 591:224-236. 
2. Drake E: Cancer chemoprevention: selenium as a prooxidant, not an antioxidant. Med Hypotheses 2006, 67:318-322.

3. Fitak B, Grabowski M, Suchocki P: Preparat przeciwnowotworowy i sposób jego wytwarzania. Pol Patent 1999, 1765301994

4. Suchocki P, Misiewicz I, Skupinska K, Waclawek K, Fijalek Z, Kasprzycka-Guttman T: The activity of Selol in multidrug-resistant and sensitive human leukemia cells. Oncol Rep 2007, 18:893-900.

5. Suchocki P, Misiewicz-Krzemiñska I, Skupiñska K, NiedŸwiecka K, Lubelska K, Fijaek Z, Kasprzycka-Guttman T: Selenitetriglicerydes affect CYP1A1 and QR activity by involvement of reactive oxygen species and Nrf2 transcription factor. Pharmacol Rep 2010, 62:352-361.

6. Bennett VA, Davies EA, Jack RH, Mak V, Moller H: Histological subtype of lung cancer in relation to socio-economic deprivation in South East England. BMC Cancer 2008, 8:139.

7. Jemal A, Siegel R, Xu J, Ward E: Cancer statistics, 2010. CA-Cancer J Clin 2010, 60:277-300.

8. Pfister DG, Johnson DH, Azzoli CG, Sause W, Smith TJ, Baker S Jr, Olak J, Stover D, Strawn JR, Turrisi AT, Somerfield MR: American Society of Clinical Oncology treatment of unresectable non-small-cell lung cancer guideline: Update 2003. J Clin Oncol 2004, 22:330-353.

9. Goldstraw P, Crowley J, Chansky K, Giroux DJ, Groome PA, Rami-Porta R, Postmus PE, Rusch V, Sobin L: International Association for the Study of Lung Cancer International Staging Committee; Participating Institutions. The IASLC Lung Cancer Staging Project: proposals for the revision of the TNM stage groupings in the forthcoming (seventh) edition of the TNM Classification of malignant tumours. J Thorac Oncol 2007, 2:706-714

10. Wakelee $\mathrm{H}$, Belani CP: Optimizing first-line treatment options for patients with advanced NSCLC. Oncologist 2005, 10:1-10.

11. Das A, Bortner J, Desai $D$, Amin S, El-Bayoumy $K$ : The selenium analog of the chemopreventive compound S, S'-(1, 4-phenylenebis [1, 2-ethanediyl]) bisisothiourea is a remarkable inducer of apoptosis and inhibitor of cell growth in human non-small cell lung cancer. Chem Biol Interact 2009, 180:158-164.

12. Azzoli CG, Temin S, Aliff T, Baker S Jr, Brahmer J, Johnson DH, Laskin JL, Masters G, Milton D, Nordquist L, Pfister DG, Piantadosi S, Schiller JH, Smith R, Smith TJ, Strawn JR, Trent D, Giaccone G: 2011 focused update of 2009 American Society of Clinical Oncology clinical practice guideline update on chemotherapy for stage IV non-small-cell lung cancer. J Clin Oncol 2009, 29:3825-3831

13. Paz-Ares L, De Marinis F, Dediu M, Thomas M, Pujol JL, Bidoli P, Molinier O, Sahoo TP, Laack E, Reck M, Corral J, Melemed S, John W, Chouaki N, Zimmermann A Visseren-Grul C, Gridelli C: Maintenance therapy with pemetrexed plus best supportive care versus placebo plus best supportive care after induction therapy with pemetrexed plus cisplatin for advanced non-squamous non-small-cell lung cancer (PARAMOUNT): a double-blind, phase 3, randomised controlled trial. Lancet Oncol 2012, 13:247-255.

14. Li Y, Li X, Wong YS, Chen T, Zhang H, Liu C, Zheng W: The reversal of cisplatin-induced nephrotoxicity by selenium nanoparticles functionalized with 11-mercapto-1-undecanol by inhibition of ROS-mediated apoptosis. Biomaterials 2011, 32:9068-9076.

15. Jastrzębski Z, Czyżewska-Szafran H, Remiszewska M: Effect of administration route on the dynamics of selol absorption, distribution and elimination. Pol J Environ Stud 1995, 6:64-66.

16. Arbos P, Arangoa M, Campanero M, Irache J: Quantification of the bioadhesive properties of protein-coated PVM/MA nanoparticles. Int J Pharm 2002, 242:129-136.

17. Fraga M, Bruxel F, Lagranha VL, Teixeira HF, Matte U: Influence of phospholipid composition on cationic emulsions/DNA complexes: physicochemical properties, cytotoxicity, and transfection on Hep G2 cells. Int J Nanomed 2011, 6:2213-2220.

18. Aubry J, Ganachaud F, Cohen Addad JP, Cabane B: Nanoprecipitation of polymethylmethacrylate by solvent shifting: 1. Boundaries. Langmuir 2009, 25:1970-1979.

19. Vitale SA, Katz JL: Liquid droplet dispersions formed by homogeneous liquid-liquid nucleation:"The ouzo effect". Langmuir 2003, 19:4105-4110.

20. Guido S, Villone M: Measurement of interfacial tension by drop retraction analysis. J Colloid Interf Sci 1999, 209:247-250.

21. Hirsjärvi S, Dufort S, Gravier J, Texier I, Yan Q, Bibette J, Sancey L, Josserand $\checkmark$, Passirani C, Benoit JP, Coll JL: Influence of size, surface coating and fine chemical composition on the in vitro reactivity and in vivo biodistribution of lipid nanocapsules versus lipid nanoemulsions in cancer models. Nanomed-Nanotechnol 2013, 9:375-387.

22. Morachis JM, Mahmoud EA, Almutairi A: Physical and chemical strategies for therapeutic delivery by using polymeric nanoparticles. Pharmacol Rev 2012, 64:505-519.

23. Wang $L$, Yang $Z$, Fu J, Yin $H$, Xiong $K$, Tan Q, Jin $H$, Li J, Wang T, Tang W, Yin J, Cai G, Liu M, Kehr S, Becker K, Zeng H: Ethaselen: A potent mammalian thioredoxin reductase 1 inhibitor and novel organoselenium anticancer agent. Free Radical Bio Med 2012, 52:898-908.

24. Suzuki M, Endo M, Shinohara F, Echigo S, Rikiishi H: Differential apoptotic response of human cancer cells to organoselenium compounds. Cancer Chemoth Pharm 2010, 66:475-484.

25. Wilczynska JD, Ksiazek I, Nowak K, Suchocki P, Flis S, Kiljan M, Anuszewska E: Study of the effect of Selol and sodium selenite on HeLa cells in vitro. CHEMIK 2011, 65:110-114.

26. Jang $S H$, Wientjes MG, Lu D, Au JLS: Drug delivery and transport to solid tumors. Pharm Res 2003, 20:1337-1350.

27. Bareford LM, Swaan PW: Endocytic mechanisms for targeted drug delivery. Adv Drug Deliver Rev 2007, 59:748-758.

28. Liu X, Wang J, Sun B, Zhang Y, Zhu J, Li C: Cell growth inhibition, G2M cell cycle arrest, and apoptosis induced by the novel compound Alternol in human gastric carcinoma cell line MGC803. Invest New Drug 2007, 25:505-517.

29. Ghiasi N, Habibagahi M, Rosli R, Ghaderi A, Yusoff K, Hosseini A, Abdullah S, Jaberipour M: Tumour suppressive effects of WEE1 gene silencing in breast cancer cells. Asian Pac J Cancer Prev 2013, 14:6605-6611.

30. Li H, Feng Z, Wu W, Li J, Zhang J, Xia T: SIRT3 regulates cell proliferation and apoptosis related to energy metabolism in non-small cell lung cancer cells through deacetylation of NMNAT2. Int J Oncol 2013, 43:1420-1430.

31. Bunnell TM, Burbach BJ, Shimizu Y, Ervasti JM: $\beta$-Actin specifically controls cell growth, migration, and the G-actin pool. Mol Biol Cell 2011, 22:4047-4058

32. Estevanato LL, Da Silva JR, Falqueiro AM, Mosiniewicz-Szablewska E, Suchocki P, Tedesco AC, Morais PC, Lacava ZGM: Co-nanoencapsulation of magnetic nanoparticles and selol for breast tumor treatment: in vitro evaluation of cytotoxicity and magnetohyperthermia efficacy. Int J Nanomed 2012, 7:5287.

33. Shinomiya N, Kuno Y, Yamamoto F, Fukasawa M, Okumura A, Uefuji M, Rokutanda M: Different mechanisms between premitotic apoptosis and postmitotic apoptosis in X-irradiated U937 cells. Int J Radiat Oncol 2000, 47:767-777.

34. Teufelhofer $O$, Weiss R, Parzefall W, Schulte-Hermann R, Micksche M, Berger W, Elbling L: Promyelocytic HL60 cells express NADPH oxidase and are excellent targets in a rapid spectrophotometric microplate assay for extracellular superoxide. Toxicol Sci 2003, 76:376-383.

35. Chen H, Zhang B, Yao Y, Chen N, Chen X, Tian H, Wang Z, Zheng Q: NADPH oxidase-derived reactive oxygen species are involved in the $\mathrm{HL}-60$ cell monocytic differentiation induced by isoliquiritigenin. Molecules 2012, 17:13424-13438.

36. Burczynski ME, Penning TM: Genotoxic polycyclic aromatic hydrocarbon ortho-quinones generated by Aldo-Keto Reductases Induce CYP 1A1 via Nuclear Translocation of the Aryl Hydrocarbon Receptor. Cancer Res 2000, 60:908-915.

37. Chen $T$, Chen $M$, Chen J: lonizing radiation potentiates dihydroartemisinininduced apoptosis of A549 cells via a caspase-8-dependent pathway. PLoS One 2013, 8:e59827.

38. Ksiazek I, Sitarz K, Roslon M, Anuszewska E, Suchocki P, Wilczynska DJ: The influence of selol on the expression of oxidative stress genes in normal and malignant prostate cells. Cancer Genomics Proteomics 2013, 10:225-232.

39. Suchocki P, Jakoniuk D, Fitak B: Specific spectrophotometric method with trifluoroacetic acid for the determination of selenium (IV) in selenitetriglycerides. J Pharm Biomed 2003, 32:1029-1036.

40. Pereira LO, Longo JPF, Azevedo RB: Laser irradiation did not increase the proliferation or the differentiation of stem cells from normal and inflamed dental pulp. Arch Oral Biol 2012, 57:1079-1085.

41. Mosmann T: Rapid colorimetric assay for cellular growth and survival: application to proliferation and cytotoxicity assays. J Immunol Methods 1983, 65:55-63.

42. Carneiro MLB, Nunes ES, Peixoto RCA, Oliveira RGS, Lourenço LHM, Silva ICR, Simioni AR, Tedesco AC, Souza AR, Lacava ZGM, Báo SN: Free Rhodium (II) 
citrate and rhodium (II) citrate magnetic carriers as potential strategies for breast cancer therapy. J Nanobiotechnology 2011, 9:11.

43. Xing JZ, Zhu L, Gabos S, Xie L: Microelectronic cell sensor assay for detection of cytotoxicity and prediction of acute toxicity. Toxicol In Vitro 2006, 20:995-1004.

44. Liu L, Ni F, Zhang J, Jiang X, Lu X, Guo Z, Xu R: Silver nanocrystals sensitize magnetic-nanoparticle-mediated thermo-induced killing of cancer cells. Acta Biochim Biophys Sin (Shanghai) 2011, 43:316-323.

45. Joanitti GA, Azevedo RB, Freitas SM: Apoptosis and lysosome membrane permeabilization induction on breast cancer cells by an anticarcinogenic Bowman-Birk protease inhibitor from Vigna unguiculata seeds. Cancer Lett 2010, 293:73-81.

46. Robertson KL, Mostaghim A, Cuomo CA, Soto CM, Lebedev N, Bailey RF, Wang Z: Adaptation of the black yeast Wangiella dermatitidis to ionizing radiation: molecular and cellular mechanisms. PLoS One 2012, 7:e48674.

doi:10.1186/s12951-014-0032-x

Cite this article as: de Souza et al:: PVM/MA-shelled selol nanocapsules promote cell cycle arrest in A549 lung adenocarcinoma cells. Journal of Nanobiotechnology 2014 12:32.

\section{Submit your next manuscript to BioMed Central and take full advantage of:}

- Convenient online submission

- Thorough peer review

- No space constraints or color figure charges

- Immediate publication on acceptance

- Inclusion in PubMed, CAS, Scopus and Google Scholar

- Research which is freely available for redistribution 